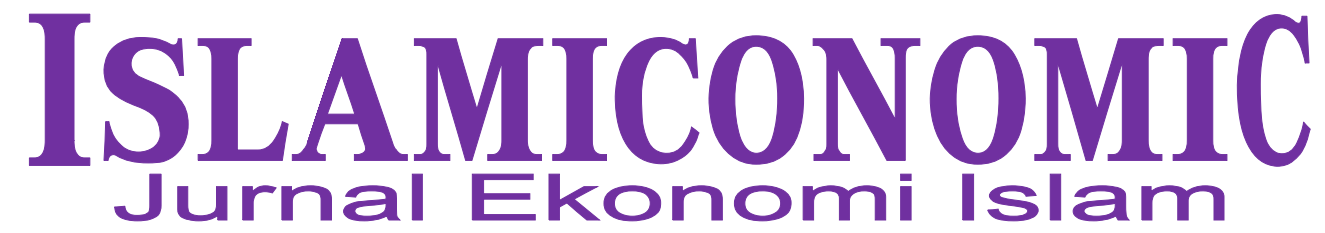

Volume 9 Nomor 2 Juli - Desember 2018

P-ISSN: 2085-3696

E-ISSN: 2541-4127

Diterbitkan oleh Jurusan Ekonomi Syariah Fakultas Ekonomi dan Bisnis Islam Universitas Islam Negeri Sultan Maulana Hasanuddin Banten

Berkala Ilmiah ini fokus dalam kajian ekonomi keuangan dan bisnis Islam, terbit dua kali dalam satu tahun (Juni dan Desember)

\title{
Redaksi Ahli
}

M. A. Tihami (UIN Sultan Maulana Hasanuddin, Banten)

Veithzal Rivai (Universitas Trisakti, Jakarta)

Asmak Ab. Rahman (University of Malaya, Malaysia)

Tulus Suryanto (UIN Raden Intan, Lampung)

Syamsuri (Universitas Darusalam Gontor, Indonesia)

Ahmad Maulidizen (IAIN Laa Roiba Bogor, Indonesia)

\section{Penanggungjawab}

Dekan Fakultas Ekonomi dan Bisnis Islam

Redaktur

Mukhlishotul Jannah

Penyunting Editor

Asep Dadan Suganda

\section{Desain Grafis}

Surahman

\section{Sekretariat}

Andi Gunawan, Ma'mun Nawawi

\section{Alamat Redaksi}

Jurusan Ekonomi Syariah

Gedung Fakultas Ekonomi dan Bisnis Islam, UIN Sultan Maulana Hasanuddin Banten

Jln. Jenderal Sudirman No. 30 Serang Telp. (0254) 200323 Fax. (0254) 200022

E-mail: islamiconomic@uinbanten.ac.id

Web: www.journal.islamiconomic.or.id 


\section{DAFTAR ISI}

Konsep Pengelolaan Koperasi Pesantren Untuk Kesejahteraan Ekonomi Masyarakat: Telaah Surah Al-Hasyr Ayat 7.

Ahmad Lutfi Rijalul Fikri, Muaidy Yasin, Akhmad Jupri $\quad 131-150$

Pengaruh Variabel Makroekonomi Terhadap Indeks Harga Saham Syariah (Studi Kasus di Indonesia dan Malaysia).

Desy Trishardiyanti Adiningtyas

$151-172$

Kajian Hukum dan Implementasi Wakaf Harta Bergerak di Indonesia: Wakaf Uang dan Saham.

Girindra Mega Paksi, Asfi Manzilati, Marlina Ekawaty

$173-190$

Literasi Keuangan Syariah dan Pondok Pesantren (Studi Kasus Pondok Modern Asy-Syifa Balikpapan).

Muhammad Khozin Ahyar

$191-210$

Analisis Zakat Produktif Terhadap Indeks Kemiskinan, Nilai Material dan Spiritual Para Mustahik.

Nono Hartono, Mohamad Anwar

$211-238$

Epistemologi Ekonomi Islam dan Maqasid Syariah Dalam Kurikulum Ekonomi Islam di Perguruan Tinggi. 